Tarbawy : Jurnal Pendidikan Islam

ISSN : 2407-4462 (Cetak), 2614-5812 (Elektronik)

Vol. 8, No. 2, 2021, Hal. 1-7

DOI: https://doi.org/10.32923/tarbawy.v8i2.1745

\title{
Perumusan Kebijakan Pendidikan Di SMP Negeri 3 Patuk
}

\author{
Ambar Wati Ningsih ${ }^{1}$, Anisa Nur Febriyani ${ }^{2}$, Joko Purwanto ${ }^{3}$, Agung Nuryahya Muhaimin ${ }^{4}$ \\ ${ }^{1}$ Universitas Ahmad Dahlan \\ ${ }^{2}$ Universitas Ahmad Dahlan \\ ${ }^{3}$ Universitas Ahmad Dahlan \\ ${ }^{4}$ Universitas Ahmad Dahlan
}

\section{Info Artikel :}

Diterima 12 Juni, 2021

Direvisi 20 Agustus, 2021

Dipublikasikan 20 oktober 2021

\section{Kata Kunci: \\ Perumusan \\ Kebijakan \\ Pendidikan}

\section{Keywords:}

Formulation

Policy

Education

\begin{abstract}
ABSTRAK
Salah satu bagian dari kebijakan publik ialah kebijakan pendidikan. Suatu kebijakan muncul karena adanya suatu permasalahan yang membutuhkan penanganan yang tepat, sehingga kebijakan tersebut dapat dijadikan sebagai pedoman. Perumusan kebijakan pendidikan merupakan suatu proses merumuskan reformasi untuk tindakan yang relevan dan dapat diterima oleh akal sehat untuk menyelesaikan berbagai masalah tertakait dengan pendidikan. Penulisan paper ini menggunakan metode kualitatif serta menggunakan pendekatan fenomenologi. Untuk memperoleh data dari observasi serta wawancara. Tujuan dibuatnya paper ini adalah untuk menjelaskan pengertian dari perumusan kebijakan pendidikan, tahapan perumusan kebijakan pendidikan, masalah yang dihadapi dalam merumuskan kebijakan pendidikan dan juga mengetahui siapa saja aktor-aktor yang terlibat dalam perumusan kebijakan pendidikan.
\end{abstract}

\begin{abstract}
One part of public policy is education policy. A policy arises because of a problem that requires proper handling, so that the policy can serve as a guide. The formulation of education policy is a process of formulating reforms for actions that are relevant and acceptable to common sense to solve various problems related to education. Writing this paper uses a qualitative method and uses a phenomenological approach. To obtain data from observations and interviews. The purpose of this paper is to explain the meaning of the formulation of educational policies, the stages of formulating educational policies, the problems faced in formulating educational policies and also to find out who are the actors involved in the formulation of educational policies.
\end{abstract}

This is an open access article distributed under the Creative Commons Attribution License, which permits unrestricted use, distribution, and reproduction in any medium, provided the original work is properly cited. 12019 by author.

\section{Koresponden:}

Ambar Wati Ningsih, Anisa Nur Febriyani, Joko Purwanto, Agung Nuryahya Muhaimin

Email: ambar1900031283@webmail.uad.ac.id, anisa1900031287@webmail.uad.ac.id,

joko1900031295@webmail.uad.ac.id, agung1900031354@webmail.uad.ac.id

\section{Pendahuluan}

Pendidikan pada hakikatnya adalah usaha sadar guna memanusiakan manusia sebagai generasi penerus yang memiliki kepiawaian serta beriman kepada Tuhan Yang Maha Esa (Bakry, 2010:3). Pendidikan merupakan kegiatan yang sangat urgen bagi warga Negara sebab pendidikan adalah sarana utama untuk meningkatkan sumber daya yang mampu mengoptimalkan potensi diri dan mampu mengelolanya secara maksimal dan bijaksana. Hal ini sesuai dengan tujuan utama pendidikan nasional yaitu mewujudkan sistem pendidikan guna meningkatkan pranata sosial yang berwibawa dan kuat sehingga mampu memberdayakan masyarakat Indonesia yang berkualitas dan proaktif dalam memecahkan tantangan zaman yang berubah-ubah.

Salah satu bagian dari kebijakan publik ialah kebijakan pendidikan dimana suatu keputusan yang dibuat secara langsung oleh pihak tertentu. Kebijakan public adalah suatu keputusan yang mengatur dan mengelola sumber daya yang ada untuk kepentingan warga negaranya. Munculnya sebuah kebijakan disebabkan adanya permasalahan yang melatarbelakangi kebijakan tersebut, sehingga kebijakan sebagai pedoman atau strategi dalam menjawab persoalan-persoalan yang ada. 
Perumusan kebijakan merupakan tahap yang paling penting dan urgen sebab implementasi dan evaluasi dapat berjalan pabila tahap perumusan kebijakan telah selesai. Pada tahap perumusan kebijakan adalah mekanisme yang sebenarnya dalam memecahkan persoalan yang telah input dalam pemerintah. Ketidak sempurnaan dalam pengelolaannya yang dapat menyebabkan kegagalan suatu kebijakan sebagian besar bersumber pada perumusan kebijakan. Proses perumusan kebijakan manganut sistem politik yang mengandalkan masukan dan dukungan dari kelompok yang berkepentingan (Bakry, 2010).

Kebijakan sebagai peran utama untuk menata kehidupan masyarakat oleh pemerintahan didalam berbagai aspek kehidupan. Salah satunya dalam bidang pendidikan. Kebijakan sebagai acuan bersifat umum yang memiliki manfaat secara operasional dapat diimplementasikan untuk suatu tujuan pendidikan. Biasanya wujud dari kebijakan pendidikan ini secara tertulis yaitu berupa Undang-undang, peraturan pemerintah, peraturan menteri dan lain-lainnya yang berkaitan dengan pendidikan.

Perumusan suatu kebijakan bukanlah sebuah uraian koseptual yang berisi pesan-pesan ideal dan normative, akan tetapi kebijakan yang dibuat harus berorientasi pada implementasi dan evaluasi. Dalam perumusannya perlu diperhatikan dari berbagai bidang aspek yang pada akhirnya akan menentukan arah dan tujuan pendidikan secara regional, nasional dan local. Perumusan kebijakan pendidikan perlu memepertimbangkan beberapa unsur-unsur yang mempengaruhi, tahapan perumusan serta aktor-aktor yang serta andil dalam perumusan kebijakan pendidikan yang akan kami ulas dalam pembahasan artikel ini.

\section{Metode Penelitian}

Artikel ini dikaji dengan menggunakan penelitian kualitatif dengan pendekatan fenomenologi. Perngumpulan data diambil dengan teknik observasi dan wawancara. Observasi dilakukan untuk mengamati secara langsung objek penelitian artikel ini. Wawancara dilakukan untuk dapat dijadikan pedoman dalam pembuatan artikel ini. Teknik tringulasi sumber dan triangulasi metode digunakan sebagai validitas data dalam pembuatan artikel ini. Tahapan yang digunakan dalam analisis data ialah mereduksi data, penyajian data, penarikan kesimpulan serta verifikasi.

\section{Pembahasan}

\section{Pengertian Perumusan Kebijakan Pendidikan}

Istilah kebijakan dan kebijaksaan walaupun sekilas penyebutannya mirip, namun antara kebijakan dan kebijaksanaan mempunyai pengertian yang berbeda. Kebijaksaan merupakan kepandaian yang ada dalam diri seseorang dalam memutuskan sesuatu, pada umumnya didasarkan pada pengalaman dan pengetahuan orang tersebut. Sedangkan istilah kebijakan mempunyai arti peraturan yang tertulis hasil keputusan dari suatu pemerintahan yang mempunyai sifat umum dan juga berlaku untuk semua elemen masyarakat.

Secara istilah kata kebijakan berasal dari kata policy yang mempunyai arti mengurus masalah atau kepentingan umum, dan juga dapat diartikan sebagai administrasi pemerintahan. Charles O.Jones mempunyai pendapat bahwa kebijakan merupakan sebuah ketetapan yang telah diputuskan bersama yang harus ditaati dan dilaksanakan oleh seluruh elemen masyarakat baik yang membuat keputusan maupun anggotanya.

Kebijakan pendidikan berasal dari dua kata yakni "kebijakan" dan "pendidikan". Tilaar dan Nugroho merupakan ahli dibidang pendidikan mempunyai pendapat bahwa kebijakan pendidikan ialah keseluruhan dari seluruh rangkaian proses yang dilaksanakan serta hasil dari perumusan mengenai langkah pasti dalam pendidikan, yang merupakan jabaran dari visi dan misi pendidikan dalam rangka untuk menyongsong pendidikan dalam menggapai tujuan bersama dalam suatu masa tertentu.

Dalam membuat kebijakan, pada umumnya pemerintah melakukan sebuah perumusan masalah supaya kebijakan tersebut tepat sasaran. Ciri khas dari perumusan masalah itu sendiri ialah dengan menjabarkan suatu masalah yang dihadapi dan menperoleh data-data terkait kondisi masalah tersebut sehingga menyebabkan adanya sebuah kebijakan. Perumusan masalah kebijakan yang ada di pendidikan ialah dengan mengusulkan serangkaian tindak nyata dinilai sebagai upaya lebih baik untuk dapat berkompromi serta otorisasi pengawasan yang salih menerima petuah serta tindakan kolektif. 
Russel L. Ackhoff menyatakan pendapatnya dalam Willian N. Dunn (2004) bahwasannya untuk dapat mencapai keberhasilan dalam memutuskan suatu masalah, kita membutuhkan suatu penemuan yang tepat terkait dengan masalah tersebut. Kegagalan yang sering kita lakukan dalam memecahkan masalah ialah karena kita sering memecahkan suatu masalah yang salah daripada mengemukakan solusi yang salah dalam masalah yang tepat. Dengan demikian dapat disimpulkan bahwa dalam memutuskan suatu masalah langkah awal yang tepat ialah dengan perumusan suatu kebijakan yang benar dan juga tepat.

Secara teknis, merumuskan kebijakan pendidikan merupakan suatu hal yang penting dari analisis kebijakan yang sedang berlaku. Oleh karena itu, tidak mengherankan jika proses pembuatan kebijakan pendidikan sering disebut sebagai siklus kebijakan pendidikan yang berkelanjutan. Perumusan kebijakan pendidikan harus hati-hati, karena tidak akan menimbulkan masalah pada pendidikan baru, dan masalah ini lebih besar dan kompleks daripada masalah pendidikan yang harus diselesaikan. (Asmad Hanisy, 2013).

Dibandingkan dengan tahapan penyusunan agenda politik, melalui berbagai analisis teknis untuk pengambilan keputusan yang terbaik, perumusan kebijakan pendidikan bersifat teknis (Hasbullah, 2015). Oleh karena itu, kebijakan pendidikan yang dirumuskan oleh pejabat yang berwenang untuk pengembangan kebijakan alternatif bertujuan untuk menyelesaikan masalah pendidikan. Alternatif kebijakan pendidikan mempertimbangkan kebutuhan untuk merumuskan perintah administratif, keputusan peradilan dan tindakan legislatif terkait dengan penyelesaian masalah kompleks di bidang pendidikan (Willian N Dunn, 2004).

Dengan demikian dapat disimpulkan bahwasanya perumusan kebijakan pendidikan adalah suatu cara untuk dapat memutuskan suatu kendala yang dibentuk oleh aktor-aktor yang berwenang dalam membuat kebijakan dalam menghadapi kendala yang ada serta dari banyaknya cara alternatif yang ada maka dipilihnya alternatif kebijakan yang paling baik.

\section{Tahapan Perumusan Kebijakan Pendidikan}

Menurut Dunn (2000:24) tahapan perumusan kebijakan pendidikan terdiri dari beberapa rangkaian dan tindakan, yang pertama adalah tahap perumusan masalah, adanya pengakuan mengenai keberadaan masalah yang terjadi. Tahap perumusan masalah terdiri dari empat fase yaitu pencarian, pendefinisian, spesifikasi lalu pengenalan. Kedua tahap penyusunan agenda, pada tahap ini suatu masalah yang terjadi akan diagendakan dengan memenuhi syarat-syarat tertentu, seperti dampak yang terjadi pada masyarakat sehingga perlu segera untuk ditangani.

Ketiga tahap formulasi kebijakan, pada tahap ini adanya usulan-usulan oleh para actor-aktor kebijakan. Menurut (Islamy,2001:92) usulan kebijakan merupakan menyusun serta mengembangkan kegiatan yang perlu diakukan untuk memecahkan masalah. Keempat adalah tahap adopsi kebijakan, keputusan kebijakan yang telah dibuat akan disepakati dan dipertimbangkan oleh pemerintah apakah suatu keputusan tersebut dapat diterima atau ditolak, apabila rancangan keputusan tersebut ditolak maka harus merumuskannya kembali dan jika rancangan keputusan tersebut dapat diterima maka kebijakan tersebut dapat disahkan kemudian diimplementasikan (Soenarko, 1998:179)

Tahap implementasi kebijakan, melaksanakan kebijakan oleh bidang-bidang administrasi dan pemerintahan ditingkat bawah. Tahap penilaian kebijakan, kegiatan untuk menilai program yang telah dilaksanakan apakah program tersebut efektif atau tidak dan akan menjadi bahan masukan untuk memeperbaiki kebijakan-kebijakan yang telah ada atau yang akan datang (Islamy, 2001:112)

Perumusan kebijakan pendidikan di SMP Negeri 3 Patuk melalui proses koordinasi dengan dewn guru, karyawan, dan juga komite. Perumusan kebijakan dilakukan di saat rapat dinas di setiap awal semester yang dihadiri juga oleh wakil komite sekolah. Tahapan proses perumusan kebijkan pendidikan di SMP Negeri 3 Patuk adalah pertama, adanya rapat dinas. Kedua, musyawarah mufakat. Ketiga, implementasi kebijakan kepada seluruh warga sekolah.

Adapun faktor yang mempengaruhi adanya sebuah perumusan kebijakan di SMP N 3 Patuk adalah faktor lingkungan dan peserta didik. Metode yang digunakan dalam perumusan kebijakan pendidikan di SMP Negeri 3 Patuk adalah dengan musyawarah mufakat untuk kebaikan sekolah. Musyawarah adalah salah satu bentuk kematangan diri dalam menyikapi permasalahan yang dihadapi. Dengan adanya musyawarah membuat kita lebih bisa menghargai pendapat orang lain. Apabila terdapat perbedaan pendapat, hal yang dilakukan ialah voting dengan suara terbanyak itulah yang menjadi keputusan. Dalam musyawarah keputusan diambil berdasarkan atas kesepakatan bersama.

\section{Masalah dalam Perumusan Kebijakan Pendidikan}


Apabila sebuah kebijakan sudah disahkan oleh pihak yang berwenang, tidak menutup kemungkinanan untuk munculnya suatu kendala. Munculnya masalah-masalah tersebut dikarenakan adanya kendala disekitar perumusan kebijakan atau statement yang diusulkan kurang jelas bahkan tidak jelas sehingga tidak dapat dipahami dengan baik. Kendala tersebut muncul disebabkan karena a) aktor yang bertugas untuk membuat suatu kebijakan pendidikan kurang memahami pengetahuan, informasi, serta persoalan yang terjadi dilingkup pendidikan baik berupa konseptual maupun substansial. b) sumber referensi yang digunakan para perumus kebijakan pendidikan yang berbeda-beda menyebabkan kebijakan diambil melalui jalan tengah. Hal tesebut mengakibatkan suatu rumusan kebijakan pendidikan dirasa ngambang atau tidak fokus pada suatu masalah tertentu. c) ketika para aktor perumus kebijakan terlalu banyak menerima informasi ataupun kurang informasi yang diterima menimbulkan ketidakjelasan statement rumusan kebijakan pendidikan. Apabila kurang dalam mendapat informasi mengenai suatu permasalahan mengakibatkan kebijakan diputuskan dengan dipilinya jalan alternatif yang sederhana. Serta apabila terlalu banyak menerima informasi, para aktor perumus kebijakan mengalami kesulitan ketika akan mensintesakan suatu persoalan serta alternatif yang akan digunakan.

Supandi (1998) berpendapat bahwasanya ada beberapa macam masalah yang terjadi dilingkup kebijakan pendidikan, yaitu:

a. Masalah prosedural, yakni masalah yang berkaitan dengan bagaimana cara pemerintah dalam mengatur serta melaksanakan kebijakan pendidikan dan juga pekerjaannya.

b. Masalah substansial, yaitu masalah yang terjadi apabila berkenaan serta konsekuensi yang terjadi dari sebuah kegiatan pendidikan.

c. Masalah distributif, ialah masalah yang dapat diselesaikan secara perorangan serta melibatakan sedikit masyarakat.

d. Masalah regulatori, yakni apabila suatu masalah menyebabkan terdapatnya hambatan serta pembatasan dalam melaksanakan kegiatan pendidikan.

e. Masalah redistributif, apabila terjadi karena berkaitan dengan tukar-menukar referensi yang terjadi pada kalangan masyarakat ataupun kelompok-kelompok.

Permasalahan yang sering dibahas dalam proses perumusan kebijakan pendidikan di SMP Negeri 3 Patuk ialah masalah substansial. Dikarenakan SMP Negeri 3 Patuk merupakan sekolah inklusi sehingga kebijakan yang dibuat harus sudah mencakup kebijakan untuk anak berkebutuhan khusus (ABK). Sekolah inklusi merupakan sekolah yang tidak membedakan antara anak yang memiliki kebutuhan khusus dengan anak pada umumnya, sehingga mereka dapat belajar bersama. Akan tetapi, selama kegiatan belajar mengajar sedang berlangsung anak berkebutuhan khusus akan tetap didampingi oleh guru pendampingnya.

Para aktor perumus kebijakan yang ada di SMP Negeri 3 Patuk tidak semua memperhatikan masalah-masalah umum maupun isu-isu yang beredar ditengah masyarakat. Sering sekali masalah umum serta isu-isu tersebut lenyap dengan sendirinya seiring dengan berjalannya waktu. Masalah umum dan isu-isu yang dipilih dan akan dibahas oleh para aktor perumus kebijakan biasa disebut dengan agenda kebijakan.

Masalah umum serta isu-isu yang mendapat perhatian oleh para aktor sehingga masalah tersebut akan dibahas dan dipecahkan masalahnya, biasanya sudah memenuhi persyaratan yang berlaku. Persyaratan yang dimaksud adalah sebagai berikut a) masalah tersebut bersifat luar biasa, maksudnya suatu masalah yang tidak biasa terjadi serta dapat berdampak besar pada masyarakat, b) masalah tersebut berkenaan dengan kepentingan para pengurus, c) masalah tersebut disiarkan secara serentak oleh semua media massa, dan d) masalah tersebut diungkapkan oleh akademikus yang mempunyai wawasan pengetahuan yang luas serta 
memandang masalah secara objektif. Akan tetapi, terdapat juga masalah serta isu-isu yang sudah memenuhi persyaratan yang ada namun tidak di perhatikan oleh pemerintah.

Di SMP Negeri 3 Patuk sendiri pernah mengalami suatu kegagalan dalam pelaksanaan kebijakan pendidikan di sekolah tersebut. Langkah yang diambil untuk mengatasi hal tersebut adalah mengevaluasi kembali kebijakan yang telah diputuskan dengan mekanisme yang prosedural. Langkah-langkah dalam mengevaluasi kebijakan adalah a) perlu adanya identifikasi terhadap suatu tujuan kebijakan, b) melukakan analisis masalah yang terjadi, c) melakukan deskripsi serta standarisasi kebijakan pendidikan, d) melakukan pengukuran secara berkala terkait dengan tingkatan perubahan dari evaluasi kebijakan, dan e) menganalisis apakah perubahan dari masalah yang dievaluasi akibat dari adanya evaluasi atau disebabkan oleh faktor yang lain.

\section{Aktor-Aktor dalam Perumusan Kebijakan Pendidikan}

Sekumpulan orang yang terlibat dan mempunyai wewenang dalam perumusan kebijakan pendidikan dinamakan aktor. Aktorlah yang memberikan sebuah dukungan ataupun sebuah tuntutan serta pula aktor menjadi sasaran dari kebijakan yang sistem kebijakan hasilkan. Hasil dari pemikiran para aktorlah yang menjadi sebuah keptusan kebijakan, dimana masing-masing miliki sebuah keterampilan yang dapat mempengaruhi, kemauan agar dapat mengolah sumber daya, dan juga mempunyai sumber-sumber pengaruh (Ariandy, 2019). Dalam merumuskan sebuah kebijakan pendidikan diperlukan aktor-aktor yang dianggap profesional. Hal tersebut dilakukan agar dapat meminimalisirkan terjadinya kesalahan pada saat proses perumusan berlangsung. berikut:

Adapun aktor-aktor yang ikut serta dalam merumuskan kebijakan pendidikan adalah sebagai

a. Legislatif

Legislatif merupakan badan yang bertugas untuk membuat undang-undang dan juga yang merumuskan kebijakan pendidikan. Legislatif merupakan aktor utamanya dikarenakan pengesahan kebijakan pendidikan, peraturan pemerintahan, dan juga peraturan daera berada dibawah kekuasaan legislatif. Aktor yang berperan disini adalah MPR, DPR, DPD, serta DPRD (Hasbullah, 2015)

b. Eksekutif

Eksekutif memegang kekuasaan untuk menerima atau menolak kebijakan yang telah disusun oleh legislatif dan juga eksekutif mendapat kebebasan untuk merancang kembali ataupun tidak merancang kembali dengan sebuah alasan yang rasional. Aktor eksekutif meliputi Presiden, Gubernur, Mentri, Walikota, Bupati dan juga Kepala Dinas. Mentri Pendidikan Nasional, Mentri Agama, Dirjen, Kepala Dinas, serta Rektor merupakan jajaran aktor eksekutif yang bergerak di bidang pendidikan. (Hasbullah, 2015)

c. Administrator

Dalam mencapai tujuan negara administrator mempunyai peranan yang penting. Administrator mempunyai peran untuk terlibat dalam merumuskan kebijakan. implementasi, dan juga evaluasi.

d. Partai Politik

Partai politik atau sering disebut parpol merupakan sebuah kelompok yang memiliki sistem organisasi yang baik serta mempunyai misi untuk mengingatkan pemerintahan supaya dapat melakukan program kerjanya dan memposisikan para anggotanya menduduki jajaran pemerintahan. Peran partai politik ialah memposisikan anggitanya di legislatif serta pimpinan negara maupun daerah.

e. Kelompok yang berkepentingan (Interest Group)

Kelompok berkepentingan merupakan sekelompok orang yang memiliki kepentingan yang sama. Kelompok ini berperan untuk mempengaruhi perumusan kebijakan supaya kepentingan dari kelompok ini dapat terakomodir.

f. Organisasi Masyrakat

Organisasi masyarakat merupakan sekumpulan orang yang mempunyai visi, misi, dan tujuan yang sama. Organisasi masyarakat dapat menyuarakan harapannya kepada para perumus kebijakan formal. 
g. Perguruan Tinggi

Perguruan tinggi merupakan suatu lembaga akademik. Perguruan tinggi merupakan penampung aspirasi dan harapan rakyat yang akan di masukkan kepadam butir-butir kebijakan.

h. Tokoh Perorangan

Tokoh perorangan terdiri dari berbagai macam bidang seperti pendidikan, keagamaan, ekonomi, politik, seni, budaya dan lain sebagainya. Dengan pemikiran yang cerdas, tokoh perorangan dapat memberikan gagasannya untuk perumus kebijakan. Maka dari itu, tokoh perorangan dapat langsung berkomunikasi dengan para perumus kebijakan formal.

Di SMP Negeri 3 Patuk sendiri aktor yang berwenang dalam merumuskan kebijakan pendidikan adalah kepala sekolah beserta para dewan guru, karyawan sekolah, dan juga pengurus komite sekolah. Hasil dari kebijakan pendidikan yang diputuskan secara musyawarah mufakat membawa dampak bagi seluruh warga sekolah diantaranya seluruh warga sekolah mempunyai kewajiban untuk mengikuti atau mentaati kebijakan pendidikan yang berlaku di sekolah tersebut. apabila terdapati tidak mengikuti atau mentaati kebijakan pendidikan yang berlaku akan dikenai sanksi yang telah disepakati bersama.

\section{Kesimpulan}

Untuk melakukan perumusan kebijakan pendidikan di SMP Negeri 3 Patuk para aktor kebijakan disekolah tersebut mengadakan koordinasi dengan dewan guru, karyawan dan juga komite sekolah. Perumusan kebijakan diadakan ketika rapat dinas di setiap awal semester. Metode yang digunakan dalam memutuskan kebijakan di SMP Negeri 3 Patuk adalah dengan menggunakan metode musyawarah mufakat, apabila terdapat perbedaan pendapat anatara para aktor maka dilakukan voting. Aktor-aktor yang berwenang dalam merumuskan kebijakan pendidikan di SMP Negeri 3 Patuk adalah kepala sekolah, para dewan gur, karyawan sekolah, serta juga komite sekolah.

Tahapan proses perumusan di SMP Negeri 3 Patuk ialah melakukan rapat dinas, tercapainya mufakat, dan implementasi kebijakan. Faktor yang mempengaruhi dirumuskannya kebijakan di SMP Negeri 3 Patuk adalah faktor lingkungan dan peserta didik. SMP Negeri 3 Patuk merupakan sekolah inklusi yang dimana menerima peserta didik reguler dan anak yang memiliki kebutuhan khusus (ABK). Kebijakan pendidikan di sekolah ini dibuat dengan mempertimbangkan kebutuhan anak berkebutuhan khusus (ABK). Di SMP Negeri 3 Patuk sendiri pernah mengalami kegagalan dalam melaksanakan kebijakan pendidikan yang berlaku. Untuk menanggulangi masalah tersebut kepala sekolah beserta dewan guru, karyawan, dan komite melakukan evaluasi kembali mengapa kebijakan tersebut bisa gagal melalui mekanisme yang prosedural.

\section{Referensi}

Arwildayanto, DKK. 2018. Analisis Kebijakan Pendidikan Kajian Teoretis, Eksploratif, dan Aplikatif. Bandung: CV Cendikia Press

Darma, I. P., \& Rusyidi, B. (2015). Pelaksanaan sekolah inklusi di Indonesia. Prosiding Penelitian dan Pengabdian kepada Masyarakat, 2(2).

Dunn, William N., (2004) Analisa Kebijakan Publik. (Peny.: Muhadjir Darwin). Yogyakarta: Gajah Mada University Press.

Fattah, Nanang. (2013). Analisis Kebijakan Pendidikan. Bandung: Remaja Rosdakarya

Hanisy, Asmad. (2013). Konsep dasar analisis kebijakan. Al Qodiri: Jurnal Pendidikan, Sosial dan Keagamaan, 4(1), 48-63.

Hasbullah. (2015), Otonomi Pendidikan:Kebijakan Otonomi Daerah dan Implikasinya Terhadap Penyelenggaraan Pendidikan. Jakarta: Raja Grafindo Persada

Lester, James P \& Stewart, Joseph JR. (2010). Public Policy: An Evolutionary Approach. USA, Wadsworth/Thomson Learning

Majdid, Abd. 2018. Analisis Kebijakan Pendidikan. Yogyakarta: Penerbit Samudra Biru 
Mohammad Ariandy, "Kebijakan Kurikulum Dan Dinamika Penguatan Pendidikan Karakter Di Indonesia," Sukma: Jurnal Pendidikan 3, no. 2 (2019): 137 $\square 168$

Quade, E.S., (1984), Analysis for Public decision. Elsevier Science Publishing, New York.

Sidney, M. S. (2007).Policy formulation: Design and tools. In F. Fischer, G. J. Miller, \& M. S. Sidney (Eds.), Handbook of public policy analysis: Theory, politics and methods (pp. 79 $\square$ 87). New Brunswick, NJ: CRC Taylor and Francis 